MEGAlE, A. (org.). Desafios e Práticas na Educação Bilíngue. São Paulo: Fundação Santillana, 2020. v.2. 136p.

\title{
ANÁLISE CRÍTICA: EDUCAÇÃO BILÍNGUE NO BRASIL - PARTE 2
}

\section{Lucas Amâncio Mateus ${ }^{1}$}

Neste segundo volume de Desafios e Práticas na Educação Bilíngue no Brasil, Antonieta Megale traz uma gama muito enriquecedora de estudos abordando as principais questões que norteiam esse processo, tais como: multiletramentos, metodologias ativas e aprendizagem baseada em problemas em contextos de salas de aula bilíngues.

A obra foi produzida objetivando, sobretudo, alcançar os questionamentos de pais e professores sobre a verdadeira necessidade do ensino bilíngue, suas dificuldades, assim como as abordagens necessárias, dentre outros fatores que ainda precisam ser incorporados à prática no Brasil, tomando como prisma o panorama global.

Um ano após o lançamento do primeiro volume, este tem por objetivo proporcionar o apoio necessário e o acesso a reflexões e pesquisas pertinentes perante o novo cenário, marcado pelo crescimento expressivo das escolas bilíngues nesse período, denotando-se, portanto, novas perspectivas, como também novos desafios.

No primeiro capítulo, Antonieta Megale trata sobre os saberes necessários para a docência em escolas bilíngues no Brasil, levando em conta o alto crescimento das escolas com essa proposta no país, sobretudo as que utilizam o inglês e português como línguas de instrução.

A proposta consiste em conceber a formação docente - em consonância com a Base Nacional Comum Curricular (BNCC) - pautada em fomentar professores que atuem como agentes e intervenientes no mundo, ou seja, desprender-se de uma prática engessada, para se

\footnotetext{
${ }^{1}$ Mestrando em Estudos Linguísticos pela Universidade Federal de Uberlândia. Graduado em Administração pela mesma universidade e Licenciado em Letras Português/Inglês pela Universidade de Franca. Lattes: http://lattes.cnpq.br/oroiro2792314230. E-mail: lucasamanciomateus@gmail.com.
} 
utilizar uma estruturação que tenha por finalidade a construção do saber através das vivências no contexto real. Para delinear o trabalho docente, foi publicada pelo MEC a BNC-Formação, documento baseado na BNCC, formado para orientação e organização dos cursos de pedagogia e licenciatura nas instituições de ensino públicas e privadas. No entanto, nada traz especificamente sobre as escolas bilíngues. $O$ documento toma por base três dimensões, quais sejam: conhecimento profissional, prática profissional e engajamento profissional.

No segundo capítulo, Maria Teresa Aranda fala sobre a implementação de uma proposta de educação bilíngue e seus principais desafios. A autora reflete acerca das modalidades já implementadas e as possibilidades que se abrem através da discussão desse sistema. Entende-se que, para implantar uma educação bilíngue de fato, demandam-se estudos aprofundados e critérios que sejam claros e consistentes, os quais envolvem escolhas curriculares. Também são necessários a integração das línguas e diferenciação de materiais didáticos, trabalho colaborativo e formação continuada da equipe.

No terceiro capítulo, Marcello Marcelino vem tratar das indagações que costumam surgir por parte das famílias ao se tratar de educação bilíngue. O que acentua essas questões é o fato de que, por não haver ainda um padrão regulamentado no Brasil, as escolas acabam por adotar diferentes modelos para essa modalidade de ensino. $O$ autor afirma que, apesar de haver questões controversas e ainda muitas disparidades nesse sistema de ensino, estudar dentro dessa modalidade, já na infância, é de grande valia e traz muitos benefícios de maneira geral.

No capítulo 4, Renata Condi de Souza aborda as metodologias ativas na Educação Bilíngue, que podem ser entendidas como a utilização de métodos ativos e criativos, tendo como agente o estudante, baseadas em uma inter-relação entre escola, sociedade, cultura e política. No contexto da Educação Bilíngue, o uso de metodologias ativas demonstra-se como uma escolha primordial para a formação do indivíduo, reconhecendo-o como cidadão global, desenvolvendo competências para "observar, refletir e mobilizar conhecimento de modo que seja linguística e culturalmente apto e respeitoso para com a sociedade em que estiver inserido" (pág. 74).

O capítulo 5, desenvolvido por Fernanda Coelho Liberali, inclui a idéia de agência em educação Mullti/Bilíngue no Brasil, elucidando que a constituição de agentes com mobilidade precisa ser o foco de uma educação inovadora, quebrando dessa forma o sistema encapsulado 
imposto através de uma ideologia monolíngue, engessada e coberta de procedimentos predeterminados.

A autora defende uma educação que seja feita para adaptação, tendo como foco formar sujeitos "focados em mudança, flexibilidade, velocidade e inovação" (pág. 82), opondo-se ao modelo tradicional que educa para a reprodução e adaptação.

No capítulo 6, Camila Dias traz algumas propostas para alfabetização e multiletramentos em contextos bilíngues, visto que se percebe um grande desafio para o desenvolvimento da leitura e escrita em crianças inseridas em contextos multilíngues devido ao acentuado crescimento do número de escolas bilíngues no Brasil. Diante disso, reforça a importância de compreender o espaço em que as crianças aprendam de forma interativa no processo de alfabetização e prática de leitura, reforçando a necessidade de promover letramento e multiletramentos em sala de aula.

A autora discorre sobre as práticas pedagógicas que têm a intenção de promover reflexões acerca dos desafios enfrentados pelos professores, tais como: práticas relacionadas aos gêneros textuais e a consciência fonológica.

O capítulo 7, sob a organização de Gladys Lopes Farias e Ingrid Puche, discorre sobre o planejamento de projetos pedagógicos em contextos bilíngues, propondo estratégias para execução dentro dessa realidade. É importante ressaltar que o objetivo de se discutir a educação bilíngue em sua totalidade teórica e prática - consiste em estabelecer o pensamento de que não se espera apenas o estudo de uma língua adicional, mas sim para ampliar o contato com novos discursos, e dessa maneira, o olhar e viver sob um panorama global e, concomitantemente, multicultural.

A fim de alcançar tais objetivos, defende-se uma abordagem de trabalho por meio de projetos, tratando o ensino de forma interdisciplinar e relacional, colocando o aluno como participante ativo dentro dessa trajetória.

No capítulo 8, Luciana de Souza Brentano expõe uma análise sobre as implicações na sala de aula no que tange à experiência bilíngue e à cognição. A autora demonstra, através de pesquisas relevantes da área, que a educação bilíngue desde a infância contribui significativamente para o desenvolvimento cognitivo, estimulando as funções executivas, as quais podem ser definidas como inibição, memória de trabalho e flexibilidade cognitiva. 
Na prática em sala de aula, a autora defende que um mero aumento de exposição à língua adicional não fará com que o aluno desenvolva aspectos cognitivos de maneira mais avançada; pelo contrário, para que isso ocorra é necessário que os conhecimentos sejam estimulados pelo uso da língua no cotidiano, não meramente pelo aumento de aulas, por exemplo.

É necessário que haja uma proposta educacional que tenha por base a criação de demandas cognitivas, proporcionando assim um desenvolvimento aprofundado, que englobe o raciocínio, a criatividade, o controle inibitório, a memória de trabalho e a flexibilidade cognitiva, para dessa maneira obter-se uma base sólida no aprendizado escolar.

Diante da análise da obra e reforçando-se o estudo através de pesquisas locais, entende-se que o ensino bilíngue - dentro das práticas ideais - contribui de maneira eficaz na formação intelectual, cognitiva e cultural, por isso é de grande valia desde o momento da alfabetização e letramento.

Uma pesquisa realizada pela Universidade de São Paulo (USP) avaliou a interferência do Ensino Bilíngue sobre as crianças. De acordo com a pesquisa, comprovou-se que a criança consegue adquirir maior controle inibitório, ou seja, diminui a dificuldade de concentração, ao ser capaz de gerenciar os diversos estímulos recebidos de forma simultânea.

Em suma, conclui-se que o crescimento do Ensino Bilíngue no Brasil é um ganho para a aprendizagem em nível global e multicultural. Sabe-se que há ainda um longo caminho a percorrer no que diz respeito à padronização das práticas de ensino e a ampliação da interdisciplinaridade nas abordagens. Entretanto, já se observa um desenvolvimento de grande valia para a construção de sujeitos agentes, com variedade cultural e formados dentro da perspectiva de respeito e equidade diante da realidade mundial. 